\title{
New records of heterobranch sea slugs (Mollusca: Gastropoda) from Isla del Coco National Park, Costa Rica
}

\author{
Kimberly García-Méndez ${ }^{1} \&$ Yolanda E. Camacho-García ${ }^{1,2,3,4}$ \\ 1. Escuela de Biología, Universidad de Costa Rica, 11501-2060 San José, Costa Rica; kimberly13@gmail.com, \\ ycamacho99@yahoo.com \\ 2. Museo de Zoología, Universidad de Costa Rica, 11501-2060 San José, Costa Rica. \\ 3. Centro de Estructuras Microscópicas (CIEMIC). \\ 4. Centro de Investigación en Ciencias del Mar y Limnología (CIMAR).
}

Received 12-VI-2015. Corrected 02-IX-2015. Accepted 08-IX-2015.

\begin{abstract}
The molluscan fauna of Isla del Coco has recently been well documented, but the heterobranch sea slugs, traditionally called "opisthobranchs", remain poorly known. We report 13 new records, increasing the total to 40 species. Of the 13 newly discovered species, the following species had not been previously recorded along the Pacific Costa Rican mainland: Berthella californica (Dall, 1900), Peltodoris rubra (Bergh, 1905), Dendrodoris albobrunnea Allan, 1933, Doriopsilla cf. spaldingi Valdés \& Behrens, 1998, Glaucus cf. marginatus (Reinhardt \& Bergh, 1864), and Flabellina sp. Additionally, we report Peltodoris rubra, previously known from the Indo-Pacific, for the first time in the Eastern Tropical Pacific. Rev. Biol. Trop. 64 (Suppl. 1): S205-S219. Epub 2016 Febrary 01.
\end{abstract}

Key words: Heterobranchia, Nudipleura, Sacoglossa, Aplysiomorpha, opisthobranch, biodiversity, new records, Isla del Coco, Cocos Island.

Among the marine species recently reported for Isla del Coco (also known as Cocos Island), the mollusks represent the most species-rich group with 490 species (Cortés, 2012). Despite the high diversity, the heterobranch molluscan fauna, traditionally referred to as "opisthobranchs", is poorly known.

The first records of the Isla del Coco opisthobranch fauna came from a molluscan checklist published by Montoya (1983). Montoya reported the cephalaspidean Bulla punctulata A. Adams in Sowerby, 1850, and four pelagic pteropods: Diacavolinia longirostris (Blainville 1821, reported as Cavolinia longirostris), Diacria quadridentata (Blainville 1821), Creseis virgula (Rang, 1828), and Heliconoides inflatus (d'Orbigny, 1834, reported as Limacina inflata). A decade later, Mulliner (1993), reported the pteropods Cavolinia uncinata (d'Orbigny, 1834), Diacria quadridentata
(Blainville 1821), Creseis clava (Rang, 1828, reported as Creseis acicula), Heliconoides inflatus (d'Orbigny, 1834, reported as Limacina inflata), Limacina bulimoides (d'Orbigny, 1834), and Limacina trochiformis (d'Orbigny, 1834), all specimens were non-living animals but the shells were collected from rock-shaken substrate. The rest of the opisthobranchs collected by Mulliner were: two anaspideans Dolabella auricularia (Lightfoot, 1786), and Dolabrifera dolabrifera (Rang, 1828), two side-gilled slugs, Pleurobranchus digueti Rochebrune, 1895 (reported as Pleurobranchus areolatus Mörch, 1863), and Berthellina ilisima Marcus \& Marcus, 1967 (reported as B. engeli Gardiner, 1936). The umbrella shell Tylodina fungina Gabb 1865, and two sacoglossans Julia thecaphora (Carpenter, 1857) and Elysia diomedea (Bergh, 1894) (reported as Tridachiella diomedea). Among the dorid nudibranchs, 
he also reported Dendrodoris krebsii (Mörch, 1863), which is probably D. fumata, and Felimida baumanni (Bertsch, 1970, reported as Chromodoris baumanni Bertsch, 1970).

Valdés, \& Camacho-García (2004) reported four species of cephalaspideans from Isla del Coco: Cylichnella defucnta (Baker \& Hanna, 1972, reported as Atys defuncta), Navanax aenigmaticus (Bergh, 1893), Cylichna atahualpa (Dall, 1908) and Volvulella catharia Dall, 1919.

Camacho-García (2009) reported 11 benthic opisthobranchs for Isla del Coco. Among the species reported that are not included in the previous studies mentioned above, are: Felimida sphoni Ev. Marcus, 1971 (reported as Chromodoris sphoni), Phestilla lugubris (Bergh, 1870), and Tambja abdere (Farmer, 1978). According to Carmona et al. (2014) Anteaeolidiella indica (Bergh, 1888), also reported in Camacho-García (2009) corresponds to Anteaeolidiella ireneae. Finally, Sibaja-Cordero,
García-Méndez, \& Troncoso (2013) reported the two nudibranchs Onchidoris sp. and an aeolid identified as Aeolidioidea indet., which were collected from sandy bottoms around the Island.

All of the previous studies bring the number of opisthobranchs of Isla del Coco to 27 species. The present study updates the knowledge on this group. We include new reports, extended distributional ranges, morphological data and illustrate some of the more relevant species for Isla del Coco.

\section{MATERIALS AND METHODS}

Study site: Isla del Coco National Park $\left(5^{\circ} 30^{\prime}-5^{\circ} 34^{\prime} \mathrm{N}-87^{\circ} 01^{\prime}-87^{\circ} 06^{\prime} \mathrm{W}\right)$ is located approximately $550 \mathrm{~km}$ southwest of Cabo Blanco, Costa Rica, and about 630 km northeast of the Galápagos Islands (Lizano, 2001) (Fig. 1). The Island is the only point above sea level of the Coco Volcanic Cordillera

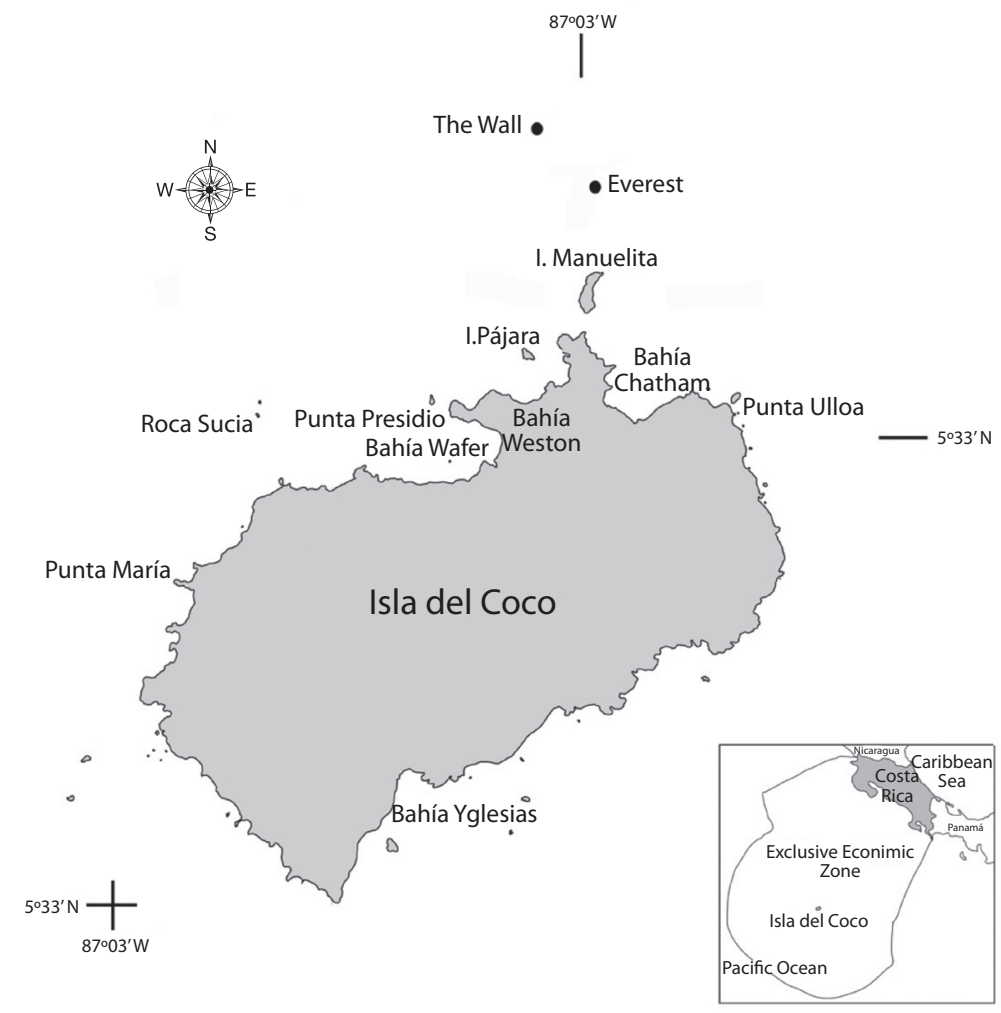

Fig. 1. Collecting sites at Isla del Coco National Park. 
that originates in the Galápagos Hotspot in the Eastern Tropical Pacific (Alvarado-Induni, 2000; Rojas, \& Alvarado, 2012). The Island measures $4.4 \times 7.6 \mathrm{~km}$, with an area of $24 \mathrm{~km}^{2}$ and the marine protected area is $1997 \mathrm{~km}^{2}$ (Cortés, 2008).

Sampling collection: Sampling was carried out during the scientific Expeditions CIMAR-MONITOREO-COCO-I and II, between 12-20 July 2013 and 23 February 05 March 2014, respectively. The specimens were collected in subtidal areas during daylight hours at six different locations. These locations were surveyed by SCUBA diving to a depth of $15 \mathrm{~m}$.

The specimens were obtained using indirect (collecting algae) and direct (collecting observed animals) methods. Specimens were brought to the laboratory on board the ship and photographed alive, then relaxed in a solution of $\mathrm{MgCl}_{2}$ with saltwater. After relaxation, the specimens were preserved in $95 \%$ ethanol. Some specimens were fixed in a Bouin's solution and then preserved in $70 \%$ ethanol for morphological studies.

The external characters such as color and morphology were used for identification according to the literature available for the region (Behrens, \& Hermosillo, 2005; Camacho-García, Gosliner, \& Valdés, 2005; Hermosillo, Behrens, \& Ríos-Jara, 2006; Gosliner, Behrens, \& Valdés, 2008) and original descriptions (MacFarland, 1905; Valdés, \& Behrens, 1998; Churchill, Valdés, \& Foighil, 2014). All specimens were collected with a permit from the Sistema Nacional de Áreas de Conservación (065-2013-SINAC, ACMIC-I-2013-0004), and deposited at the Museo de Zoología, Universidad de Costa Rica (MZUCR).

Additionally, we included specimens already deposited at the Museo de Zoología that were collected on different expeditions to Isla del Coco carried out by the Santa Barbara Museum of Natural History and the Centro de Investigación en Ciencias del Mar y Limnología (CIMAR), between 1997 (SBMNH), and 2007 to 2014 (CIMAR). Finally, we also include specimens from deep waters that were filmed or photographed by the submersible DeepSee (Cortés, \& Blum, 2008), although just a few of these records have a voucher specimen deposited at MZUCR.

\section{RESULTS}

A total of 13 species were collected from Isla del Coco, increasing the total known opisthobranch fauna to 40 species. Of the 13 species, the following species represent new records for the Pacific Costa Rican mainland: Berthella californica (Dall, 1900), Peltodoris rubra (Bergh, 1905), Dendrodoris albobrunnea Allan, 1933, Doriopsilla cf. spaldingi Valdés \& Behrens, 1998, Glaucus cf. marginatus (Reinhardt \& Bergh, 1864), and Flabellina sp. The record of Peltodoris rubra from Isla del Coco, represents an important range extension on the geographic distribution of this species, as it has never been reported in the Eastern Tropical Pacific.

\section{SYSTEMATICS}

UMBRACULIDA Odhner, 1939

Family Umbraculidae Dall, 1889 (1827)

Umbraculum umbraculum (Lightfoot, 1786)

Fig. 2A

\section{Synonyms}

Parmophorus patelloide Cantraine, 1835; Patella ombracula Blainville, 1819; Patella sinica Gmelin, 1791; Patella umbraculum Lightfoot, 1786; Patella umbrellata Delle Chiaje, 1830; Umbraculum bermudense (Mörch, 1875); Umbraculum botanicum Hedley, 1923; Umbraculum chinense Schumacher, 1817; Umbraculum indicum (Lamarck, 1819); Umbraculum mediterraneum (Lamarck, 1819); Umbraculum ovalis (Carpenter, 1856); Umbraculum plicatulum (Martens, 1881); Umbraculum pulchrum Lin, 1981; Umbraculum sinicum (Gmelin, 1791); Umbrella indica Lamarck, 1819; Umbrella lamarckiana Récluz, 1843; Umbrella mediterranea Lamarck, 1819. 


\section{Material}

Isla del Coco National Park, Bahía Weston, 14.07.2013, 1 specimen, $36 \mathrm{~mm}$ long by $27 \mathrm{~mm}$ wide, $10 \mathrm{~m}$ deep, under a rock, leg. Jeffrey Sibaja-Cordero (MZUCR9822-01, photo).

\section{Remarks}

The genus Umbraculum Schumacher, 1817 is known from both temperate and tropical seas. According to Wägele, Vonnemann, \& Rudman (2006), the genus Umbraculum comprises only one species with a worldwide distribution. The morphological and molecular data support $U$. umbraculum as the only species of the genus present in both tropical and temperate waters.
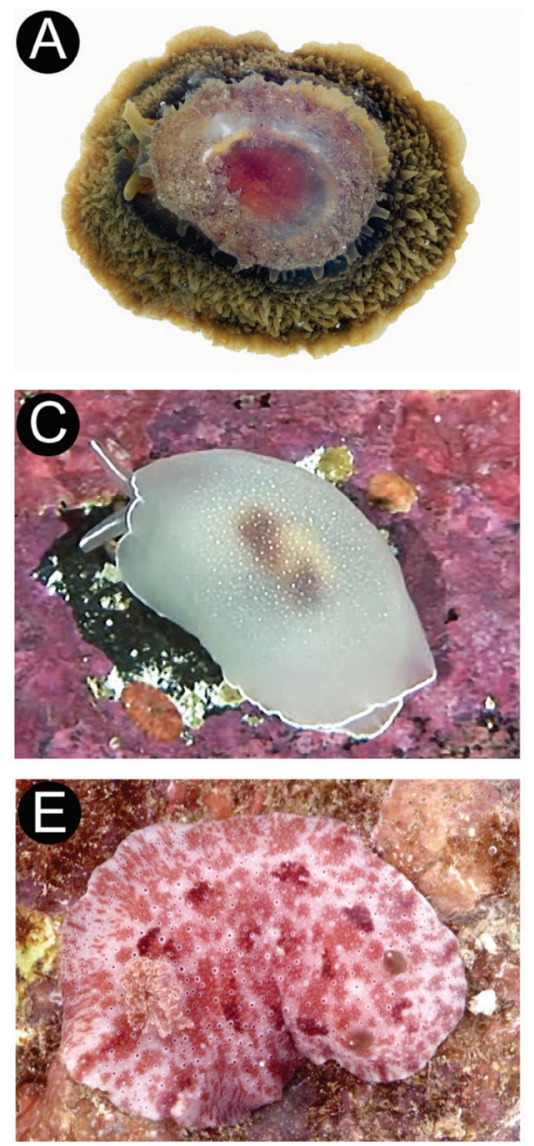

SACOGLOSSA Von Ihering, 1876

Family Plakobranchidae Gray, 1840

Elysia sp.

Fig. 2B

\section{Synonyms}

Elysia sp. 2 Camacho-García et al., 2005: 65, upper photo. Elysia sp. 1 Kaiser, 2007: 50, pl. 42 , fig. 5.

\section{Material}

Isla del Coco National Park, Canal Isla Ulloa, 01.03.2014, 7 specimens, 5-12 mm. preserved length, $5 \mathrm{~m}$ deep, leg. Kimberly García-Méndez (MZUCR9876-01, photo; MZUCR9876-02, photo; MZUCR9876-03,
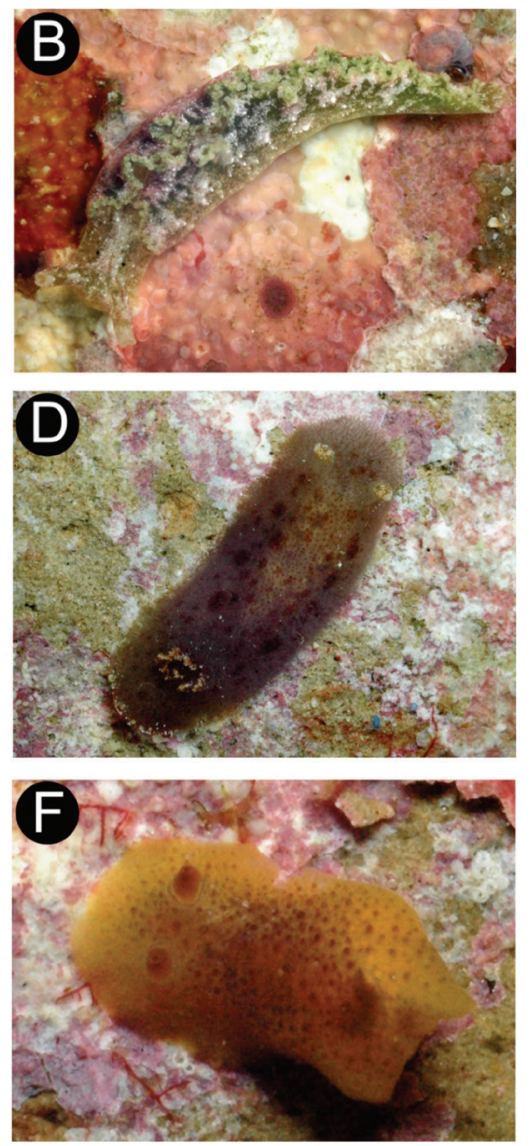

Fig. 2. (A) Umbraculum umbraculum (B) Elysia sp. (C) Berthella californica (D) Jorunna tempisquensis (E) Peltodoris rubra (F) Geitodoris mavis. Photos: Kimberly García-Méndez (A, B, D \& F), Under Sea Hunter Group (C) and Jeffrey Sibaja-Cordero (E). 
photo; MZUCR9876-04, photo; MZUCR987605, photo; MZUCR9876-06, photo; MZUCR9876-07, photo;); Isla del Coco National Park, Punta María, 26.02.2014, 9 specimens, $5-12 \mathrm{~mm}$ preserved length, $7 \mathrm{~m}$ deep, leg. Kimberly García-Méndez (MZUCR9872-01, photo; MZUCR9872-02, photo; MZUCR987203, photo; MZUCR9872-04, photo; MZUCR9872-05, photo; MZUCR9872-06, photo; MZUCR9872-07, photo; MZUCR987208, photo); Isla del Coco National Park, Punta Presidio, 25.02.2014, 2 specimens 5-6 mm, preserved length, 5-9 $\mathrm{m}$ deep, on green algae, leg. Kimberly García-Méndez (MZUCR987101, MZUCR9871-02).

\section{Morphological comments}

The body is elongated and the parapodia completely fused, the edges of these are distinctly crenulated. The rhinophores are long and rolled. The body is olive green. The edges of the parapodia are light green with some white and pink spots that are also present on the rhinophores.

\section{Remarks}

This is an undescribed species known from the Eastern Tropical Pacific, from Baja California to Costa Rica and Islas Revillagigedo (Camacho-García et al., 2005), including Clipperton Island (Kaiser, 2007). This species has also been collected in Panama (Camacho-García, in prep.) In Costa Rica, there are a few records of this species from the Pacific mainland found on the green algae Codium isabelae W.R. Taylor, 1945, Halimeda discoidea Decaisne, 1842,Caulerpa sp. and Cladophora sp. At Isla del Coco this species is very abundant on the filamentous green algae Chlorodesmis caespitosa J. Agardh 1887 (García-Méndez, 2015).
ANASPIDEA Fischer, 1883

Family Aplysiidae Lamarck, 1809

Stylocheilus striatus (Quoy \& Gaimard, 1832)

\section{Synonyms}

Aplysia striata Quoy \& Gaimard, 1832; Notarchus polyomma Mörch, 1863; Stylocheilus lineolatus Gould, 1852.

\section{Material}

Isla del Coco National Park, Bahía Chatham, 24.03.1997, 1 specimen, $12 \mathrm{~mm}$ preserved length, 0msnm, leg. Yolanda Camacho-García (MZUCR-INB0001498454); Isla del Coco National Park, Punta Presidio, 28.02.2014, 3 specimens 10-12 mm preserved length, $12 \mathrm{~m}$ deep, on a rock, leg. Kimberly García-Méndez (MZUCR9875-02, photo; MZUCR9875-03, photo; MZUCR9875-06, photo); Isla del Coco National Park, Punta María, 26.02.2014, 1 specimen, $6 \mathrm{~mm}$ preserved length, $7 \mathrm{~m}$ deep, on the red algae Polysiphonia sp. (GarcíaMéndez, 2015), leg. Kimberly García-Méndez (MZUCR9873-01, photo).

\section{Remarks}

This species has a circumtropical distribution (Camacho-García et al., 2005).

\section{NUDIPLEURA Wägele \& Willan, 2000 PLEUROBRANCHOMORPHA Pelseneer, 1906 \\ Family Pleurobranchidae Gray, 1827 \\ Berthella californica (Dall, 1900)}

Fig. 2C

\section{Synonyms}

Pleurobranchus californicus Dall, 1900; Pleurobranchus californicus denticulatus MacFarland, 1966. 


\section{Material}

Isla del Coco National Park, Everest, 18.01.2008, 1 specimen, 80-86 $\mathrm{m}$ deep, on encrusting red algae and rocks. There is no voucher specimen for this species, only a photograph taken by the DeepSee Submersible.

\section{Remarks}

Known from Peter the Great Bay (Russia) to Point Craven in Alaska, Canada, Baja California (México) to Isla Coiba (Panamá), and the Galápagos Islands (Behrens, 2004; Hermosillo, 2004; Behrens, \& Hermosillo, 2005; Camacho-García et al., 2005). This species has never been recorded on the Pacific Costa Rican mainland.

NUDIBRANCHIA Cuvier, 1817

EUCTENIDIACEA Tardy, 1970

Family Discodorididae Bergh, 1891

Geitodoris mavis (Marcus \& Marcus, 1967) Fig. 2F

\section{Synonyms}

Discodoris mavis Marcus \& Marcus, 1967, Camacho-García, \& Gosliner, 2008.

\section{Material}

Isla del Coco National Park, Bahía Yglesias, 27.02.2014, 1 specimen, $6 \mathrm{~mm}$ preserved length, $15 \mathrm{~m}$ deep, under a rock, leg. Kimberly García-Méndez (MZUCR9874-03, photo).

\section{Remarks}

This species has been reported from Bahía de los Ángeles, Baja California (México) to Nayarit (México), the Pacific mainland of Costa Rica and Galápagos Islands (CamachoGarcía et al., 2005; Hermosillo et al., 2006; Camacho-García, \& Gosliner, 2008; Bertsch, 2008; Bertsch, 2014). This is the first record for Isla del Coco.

\section{Jorunna tempisquensis \\ Camacho-García \& Gosliner, 2008}

Fig. 2D

\section{Material}

Isla del Coco National Park, Punta Presidio, 28.02.2014, 6 specimens, 5-10 mm preserved length, $12 \mathrm{~m}$ deep, under rocks, leg. Kimberly García-Méndez. (MZUCR9875-08, photo; MZUCR9875-09, photo; MZUCR9875-10, photo; MZUCR9875-11, photo; MZUCR987512 , photo).

\section{Remarks}

This species has been reported for Bahía de los Ángeles, Baja California (México), Bahía Banderas (México) and for the Pacific mainland of Costa Rica (Hermosillo et al., 2006; Camacho-García, \& Gosliner, 2008; CamachoGarcía, 2009; Bertsch, 2014). This species represents a new record for Isla del Coco.

\section{Peltodoris rubra (Bergh, 1905)}

Fig. 2E

\section{Synonyms} 1969.

Archidoris hawaiiensis Kay \& Young,

\section{Material}

Isla del Coco National Park, Bahía Weston, 02.07.2011, 1 specimen, $58 \mathrm{~mm}$ preserved length, $10 \mathrm{~m}$ deep, under a rock, leg. Jeffrey Sibaja-Cordero (MZUCR8483, photo).

\section{Morphological comments}

Body oval, elongate. Background color light pink to dark reddish brown. Dorsum with numerous red-brown patches, and spots of the same colors. Dorsum also covered with numerous small rounded white tubercles speckled with red on the tips. Rhinophores reddish brown, with white tips. Gill light pink with 
whitish lines. Ventral mantle and foot with numerous dark red spots.

\section{Remarks}

If we follow Dayrat (2010), the generic name for this species would be "Montereina". However, we decided not to follow this classification because this generic name represents a group of several species that cannot be characterized by any diagnostic character or geographic distribution. Due to the lack of consensus on the phylogenetic relationships of Discodoridae, which are unresolved until now, and in order to avoid any taxonomical confusion we prefer to use the generic name Peltodoris for this species. This species has been reported from the Indo-West Pacific and Central Pacific (Gosliner et al., 2008). This species is a new record for the Tropical Eastern Pacific. Considering that this is a substantial range extension, this record will need to be confirmed using morphological and molecular techniques.

Family Dendrodorididae O'Donoghue, 1924 (1864)

Dendrodoris albobrunnea Allan, 1933

Fig. 3A

\section{Material}

Isla del Coco National Park, Punta Presidio, 18.07.2013, 1 specimen, $30 \mathrm{~mm}$ preserved length, 8-12 m deep, under a rock, leg. Kimberly García-Méndez. (MZUCR9824-02, photo).

\section{Remarks}

This species has been reported from the western Indian Ocean of Tanzania to Papua New Guinea and Vanuatu; in the Eastern Tropical Pacific from Isla Coiba (Panamá) to Colombia, and Clipperton Island (Hermosillo, 2004; Camacho-García et al., 2005; Kaiser, 2007; Gosliner et al., 2008). Dendrodoris albobrunnea has never been found on the Pacific Costa Rican mainland.

\section{Doriopsilla janaina}

Er. Marcus \& Ev. Marcus, 1967

\section{Material}

Isla del Coco National Park, Isla Pájara, 14.11.2014, 1 specimen, $23 \mathrm{~mm}$ preserved length, 9-12 m deep, under a rock, leg. Carolina Salas-Moya (MZUCR10119-02, photo).

\section{Remarks}

This species has been reported from Bahía de los Ángeles, Baja California (México) to Bahía de Banderas (México), El Salvador, Costa Rica, Parque Nacional Coiba (Panamá), and Galápagos Islands (Gosliner, 1991; San Martín et al., 1997; Behrens, \& Hermosillo, 2005; Camacho-García et al., 2005; Bertsch, 2008; Barraza, 2009).

\section{Doriopsilla cf. spaldingi Valdés \& Behrens, 1998}

Fig. 3B

\section{Material}

Isla del Coco National Park, Wall 0475, 1 specimen, 301-304 m deep. Isla del Coco National Park, Piedra Drop: 1 specimen, 300$308 \mathrm{~m}$ deep on rock. There are no voucher specimens for this species, only the DeepSee Submersible took several photographs during the following years: 11.03.2009, 14.05.2009, 03.11.2009, and 23.07.2010.

\section{Morphological comments}

All the photographed specimens have a translucent white body, with conical tubercles on the dorsum, and a mantle margin with an iridescent blue band as in the original description (Valdés, \& Behrens, 1998). In this description, the 4-5 branchial leaves are bipinnate, and the rhinophores and branchial leaves are short. In contrast, in our specimens, the rhinophores are relatively long and the 4-5 branchial leaves are tripinnate and spreading. Herein, in the absence 

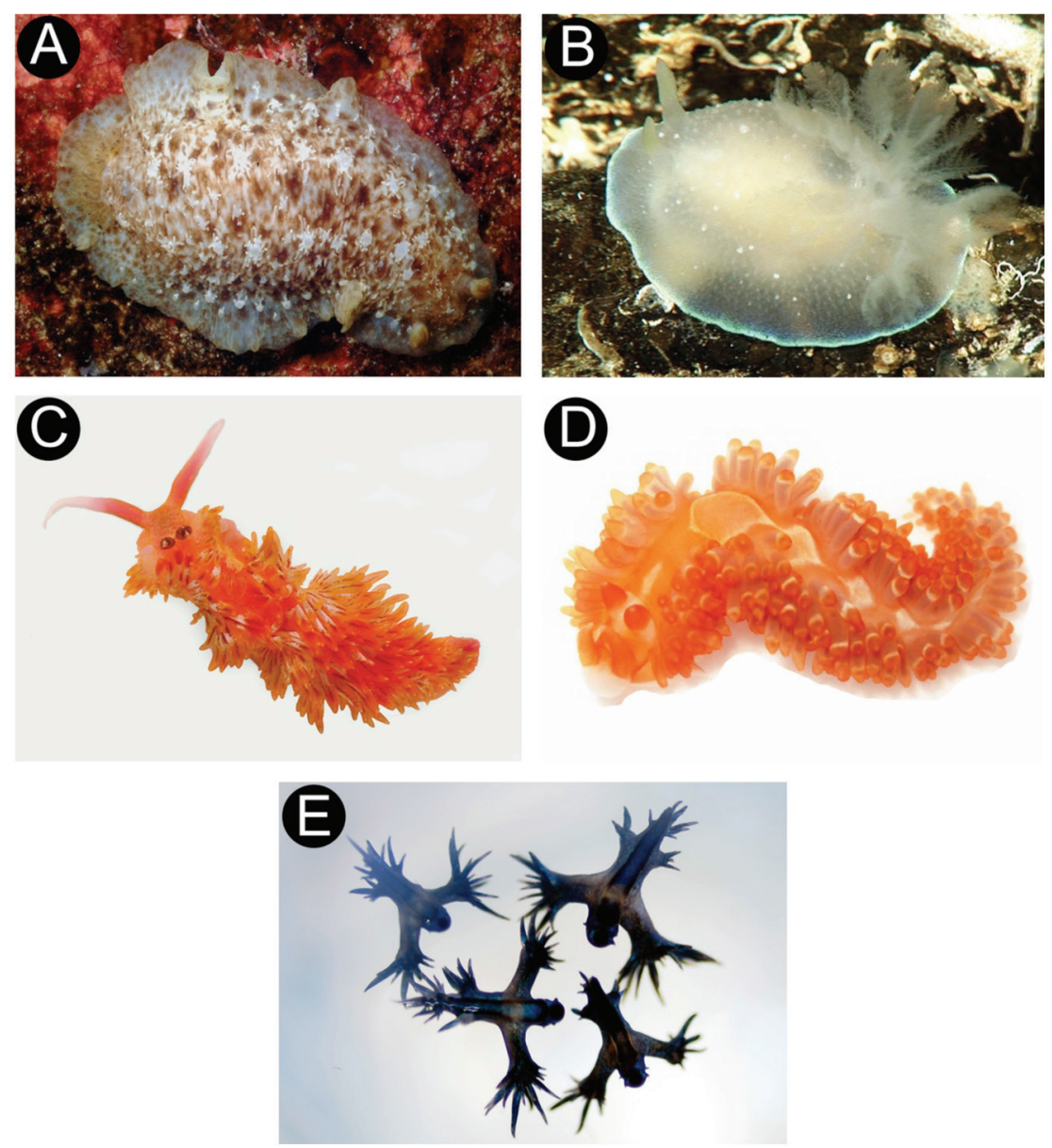

Fig. 3. (A) Dendrodoris albobrunnea (B) Doriopsilla cf. spaldingi (C) Flabellina sp. (D) Anteaeolidiella ireneae (E) Glaucus cf. marginatus. Photos: Kimberly García-Méndez (A), Under Sea Hunter Group (B), Shmulik Blum (C), Juan Manuel Camargo (D) and Felipe López-Pozuelo (E).

of voucher specimens, we identify this species tentatively as Doriopsilla cf. spaldingi.

\section{Remarks}

This species is distributed along the Pacific coast of the United States and Mexico, from Carmel California to Punta Banda, Baja California, and Guaymas, Sonora (Valdés, \& Behrens, 1998; Hermosillo et al., 2006). This species has not been recorded from the Pacific Costa Rican mainland.
CLADOBRANCHIA Willan \& Morton, 1984 Family Flabellinidae Bergh, 1889

Flabellina cf. marcusorum Gosliner \& Kuzirian, 1990

\section{Material}

Isla del Coco National Park, Yglesias Bahía, 27.02.2014, 1 specimen, $4 \mathrm{~mm}$ preserved length, $15 \mathrm{~m}$ deep, under rocks, leg. Kimberly García-Méndez (MZUCR9874-02, photo); Isla del Coco National Park, Punta 
Presidio, 28.02.2014, 3 specimens, 3-4 mm preserved length, $12 \mathrm{~m}$ deep, under rocks, leg. Kimberly García-Méndez (MZUCR987501, photo; MZUCR9875-05, photo; MZUCR 9875-07, photo).

\section{Remarks}

This species has been reported from Isla Cedros off Baja California to Sayulita and Bahía Banderas, Nayarit (México) (Gosliner, \& Kuzirian, 1990), El Salvador, Pacific mainland of Costa Rica to Islas Galápagos (Sánchez, 2000; Camacho-García et al., 2005; Hermosillo et al., 2006; Barraza, 2009), and Guayaquil, Perú (Nakamura, 2006). Another population has been reported from the Caribbean coast of South America to Brazil (Camacho-García et al., 2005; García-García, Domínguez, Troncoso, 2008). Molecular research on this species should be done in order to clarify the identity of the two Pacific and Caribbean populations.

\section{Flabellina sp.}

Fig. 3C

\section{Synonyms}

Flabellina sp. Gosliner, 1991; CamachoGarcía et al., 2005: 100, lower photo.

\section{Material}

Isla del Coco National Park, Everest, 18.10.2013, 1 specimen, $27 \mathrm{~mm}$ preserved length, $80 \mathrm{~m}$ deep, on top of coral, leg. Jorge Cortés (MZUCR9888-01, photo). Additionally, there are nine photographic records taken by the DeepSee Submersible from the Everest and The Wall during 2007 to 2010.

\section{Morphological comments}

The general body color is bright red to orange. The oral tentacles are similarly colored and have an opaque white tip. Rhinophores are brown and white tipped. Cerata orange with brown, with some whitish pigment.

\section{Remarks}

This is an undescribed species from the Eastern Tropical Pacific. It has been reported only from Galápagos (Gosliner, 1991; Camacho-García et al., 2005), and it has not been recorded on the Pacific Costa Rican mainland.

Family Aeolidiidae Gray, 1827

Anteaeolidiella ireneae Carmona et al., 2014 Fig. 3D

\section{Synonyms}

Aeolidiella indica Camacho-García et al., 2005: 110: upper photo. Anteaeolidiella sp. A Carmona, Pola, Gosliner, \& Cervera, 2013: 6.

\section{Material}

Isla del Coco National Park, Isla Pájara, 14.11.2014, 1 specimen, $17 \mathrm{~mm}$ preserved length, 9-12 m deep, under rock, leg. Carolina Salas-Moya (MZUCR10119-01, photo).

\section{Morphological comments}

For a complete description, see Carmona et al. (2014).

\section{Remarks}

Recently Carmona et al. (2014), conducted a systematic review of the genus Anteaeolidiella based on morphological and molecular data. They concluded that what had been called Aeolidiella indica from the Eastern Tropical Pacific is a new species they named Anteaeolidiella ireneae. Anteaeolidiella ireneae is reported from Clipperton Island, Isla Canal de Afuera (Panamá), Bahía de San Marte (México), Isla Socorro (México), and the Pacific coast of Costa Rica. The identity of Anteaeolidiella indica remains unclear. 
Family Glaucidae Gray, 1827

Glaucus cf. marginatus

(Reinhardt \& Bergh, 1864)

Fig. 3G

\section{Synonyms}

Glaucilla briareus Reinhardt \& Bergh, 1864; Glaucilla marginata Reinhardt \& Bergh, 1864.

\section{Material}

Provided here is a photographic record of this species taken at Isla del Coco National Park on 25.01.2008. The four living specimens were found washed up on the beach.

\section{Morphological comments}

For a complete description, see Churchill et al. (2014). The specimens in the photograph match the description from Churchill et al. (2014) identified as Glaucus marginatus. This species belongs to the informal group 'Marginatus' (Churchill, Alejandrino, Valdés, \& Foighil, 2013; Churchill et al., 2014).

\section{Remarks}

Recently, morphological and molecular phylogenetic studies on the genus Glaucus revealed that Glaucus atlanticus Forster, 1777 is a cosmopolitan species, whereas the informal clade 'Marginatus' is constituted by four cryptic species with Indo-Pacific distribution. This clade includes Glaucus marginatus (Reinhardt \& Bergh, 1864) from the tropical and subtropical Indo-Pacific region, Glaucus bennettae Churchill, Valdés \& Ó Foighil, 2014, which occurs only in the South Pacific; Glaucus thompsoni Churchill, Valdés \& Ó Foighil, 2014, and Glaucus mcfarlanei Churchill, Valdés \& Ó Foighil, 2014, from the North Pacific Ocean (Churchill et al., 2013; 2014). In our case, the specimens are consistent with the external morphology of the clade 'Marginatus', possibly G. marginatus, G. thompsoni or G. mcfarlanei mainly due to their geographic distribution. There is one photographic record for this species and identification through morphological and molecular techniques is not possible.

\section{DISCUSSION}

Studies of the opisthobranch fauna from the eastern Pacific oceanic islands are scarce; the majority of research has been done in the Galápagos Islands (Gosliner, 1991). In the present study, the number of opisthobranch species reported from Isla del Coco increase by 13 species, from 27 to 40 , a $32 \%$ increase (Table 1). Excluding the eight species of pelagic thecosomes, which have different distributional

TABLE 1

Heterobranch sea slugs recorded from Isla del Coco National Park

ORDER CEPHALASPIDEA

Family Bullidae

Bulla punctulata A. Adams in Sowerby, $1850 \quad$ EP

Family Cylichnidae

Cylichnella defuncta (Baker \& Hanna, 1972) $\quad$ EP

Cylichna atahualpa (Dall, 1908) EP

Family Rhizoridae

Volvulella catharia Dall, $1919 \quad$ EP

Family Aglajidae

Navanax aenigmaticus (Bergh, 1893) EP

ORDER THECOSOMATA

Family Cavoliniidae

Diacavolinia longirostris (Blainville, 1821) 
TABLE 1 (Continued)

\begin{tabular}{|c|c|}
\hline Taxon* & Distribution \\
\hline Diacria quadridentata (Blainville, 1821) & $\mathrm{P}$ \\
\hline Cavolinia uncinata (d’Orbigny, 1834) & $\mathrm{P}$ \\
\hline \multicolumn{2}{|l|}{ Family Creseidae } \\
\hline Creseis virgula (Rang, 1828) & $\mathrm{P}$ \\
\hline Creseis clava (Rang, 1828) & $\mathrm{P}$ \\
\hline \multicolumn{2}{|l|}{ Family Limacinidae } \\
\hline Heliconoides inflatus (d'Orbigny, 1834) & $\mathrm{P}$ \\
\hline Limacina bulimoides (d’Orbigny, 1834) & $P$ \\
\hline Limacina trochiformis (d’Orbigny, 1834) & $\mathrm{P}$ \\
\hline \multicolumn{2}{|l|}{ ORDER ANASPIDEA } \\
\hline \multicolumn{2}{|l|}{ Family Aplysiidae } \\
\hline Dolabella auricularia (Lightfoot, 1786) & CT \\
\hline Dolabrifera dolabrifera (Rang, 1828) & $\mathrm{CT}$ \\
\hline Stylocheilus striatus (Quoy \& Gaimard, 1832) & $\mathrm{CT}$ \\
\hline \multicolumn{2}{|l|}{ ORDER SACOGLOSSA } \\
\hline \multicolumn{2}{|l|}{ Family Juliidae } \\
\hline Julia thecaphora (Carpenter, 1857) & EP \\
\hline \multicolumn{2}{|l|}{ Family Plakobranchidae } \\
\hline Elysia diomedea (Bergh, 1894) & EP \\
\hline Elysia sp. & EP \\
\hline \multicolumn{2}{|l|}{ ORDER UMBRACULIDA } \\
\hline \multicolumn{2}{|l|}{ Family Umbraculidae } \\
\hline Umbraculum umbraculum (Lightfoot, 1786) & СТ \\
\hline \multicolumn{2}{|l|}{ Family Tylodinidae } \\
\hline Tylodina fungina Gabb, 1865 & EP \\
\hline \multicolumn{2}{|l|}{ ORDER PLEUROBRANCHOMORPHA } \\
\hline \multicolumn{2}{|l|}{ Family Pleurobranchidae } \\
\hline Pleurobranchus digueti Rochebrune, 1895 & EP \\
\hline Berthellina ilisima Marcus \& Marcus, 1967 & EP \\
\hline Berthella californica (Dall, 1900) & NP, EP \\
\hline \multicolumn{2}{|l|}{ ORDER NUDIBRANCHIA } \\
\hline \multicolumn{2}{|l|}{ Suborder DORIDACEA } \\
\hline \multicolumn{2}{|l|}{ Family Polyceratidae } \\
\hline Tambja abdere (Farmer, 1978) & EP \\
\hline \multicolumn{2}{|l|}{ Family Dendrodorididae } \\
\hline Dendrodoris albobrunnea Allan, 1933 & IP, EP \\
\hline Dendrodoris fumata (Mörch, 1863) & IP, EP \\
\hline Doriopsilla janaina Er. Marcus \& Ev. Marcus, 1967 & EP \\
\hline Doriopsilla cf. spaldingi Valdés \& Behrens, 1998 & NP \\
\hline \multicolumn{2}{|l|}{ Family Chromodorididae } \\
\hline Felimida baumanni (Bertsch, 1970) & EP \\
\hline Felimida sphoni (Ev. Marcus, 1971) & EP \\
\hline \multicolumn{2}{|l|}{ Family Discodorididae } \\
\hline Geitodoris mavis (Marcus \& Marcus, 1967) & EP \\
\hline Jorunna tempisquensis Camacho-García \& Gosliner, 2008 & EP \\
\hline Peltodoris rubra (Bergh, 1905) & IP \\
\hline
\end{tabular}


Family ONCHIDORIDIDAE

Onchidoris sp.

EP

Suborder AEOLIDACEA

Family Flabellinidae

Flabellina sp.

EP

Flabellina marcusorum Gosliner \& Kuzirian, 1990

Car, EP, WA

Family Tergipedidae

Phestilla lugubris (Bergh, 1870)

IP, EP

Family Glaucidae

Glaucus cf. marginatus (Reinhardt \& Bergh, 1864)

NP, IP?

Family Aeolidiidae

Antaeolidiella irenae Carmona et al., 2014

EP

*Taxa in boldface type $=$ new records for Isla del Coco.

Distribution: Car=Caribbean; $\mathrm{CT}=$ circumtropical, $\mathrm{EP}=$ Eastern Pacific; IP=Indo-Pacific; $\mathrm{NP}=$ North Pacific; $\mathrm{P}=\mathrm{Planktonic}$; WA $=$ Western Atlantic.

patterns than the benthic opisthobranchs (Lalli, \& Gilmer, 1989; Klussmann-Kolb, \& Dinapoli, 2006), Isla del Coco shows an increase of 23 species and a $18 \%$ increase of the total of species recorded for the Pacific mainland of Costa Rica (126 spp., Camacho-García, 2009). Additionally, we are including 13 new records of opisthobranchs for Isla del Coco, where seven of these species are new distributional records from the Pacific Costa Rican mainland.

In comparison to Islas Galápagos, the number of opisthobranch species found at Isla del Coco is similar. In contrast to Galápagos, three species recorded at Isla del Coco have IndoPacific distributions: Phestilla lugubris (Bergh, 1870), Dendrodoris albobrunnea Allan, 1933, and Peltodoris rubra (Bergh, 1905). The last species had never been reported for the Eastern Tropical Pacific (Gosliner 1991). Overall, the geographical affinities of the Isla del Coco opisthobranch fauna are clearly most related to the Panamic Province. Its position as the first point of contact with the Northern Equatorial Countercurrent (Cortés, 1997), makes the island one of the first possible settlement areas for larvae transported by this current through the Pacific Ocean, before arriving to the eastern Pacific mainland.
The most diverse "opisthobranch" groups at Isla del Coco are both the nudibranch dorids and aeolids, comprising almost a third of the species, which corresponds to the general trend observed along the Pacific Costa Rican mainland (Camacho-García, 2009). It is noteworthy to mention that several common herbivorous species such as Elysia pusilla (Bergh, 1872), Oxynoe panamensis Pilsbry \& Olson, 1943, and Phyllaplysia padinae (Williams \& Gosliner, 1973), found along the Pacific Costa Rican mainland, appear to be absent at Isla del Coco. Both patterns are probably the result of habitat characteristics such as the presence of reef ecosystems that provide a three-dimensional habitat for sponges, tunicates, bryozoans and hydroids, which are the preferred prey for most nudibranch dorids, and aeolids (Bruno, \& Bertness, 2001; Camacho-García, 2009). On the other hand, there is a low habitat complexity provided by macroalgae, due to the dominance of calcareous red algae and filamentous green algae (Fernández, 2008) that could be affecting the composition of the opisthobranch herbivorous species at the Island.

In conclusion, this study updates the knowledge of the opisthobranch fauna of Isla del Coco. We are convinced that the inventory of these mollusks is far from complete and 
more studies are needed to enhance the knowledge of the opisthobranch fauna from Isla del Coco. Future surveys should include various sampling techniques designed to collect cryptic species, including nighttime surveys, deepwater exploration and ecological research. All of these techniques combined will help us to better understand the biodiversity of the opistobranch fauna of Isla del Coco.

\section{ACKNOWLEDGMENTS}

The fieldwork at Isla del Coco in 1997 was carried out by YCG on board the Undersea Hunter as part of an Expedition by the Santa Barbara Museum of Natural History, led by Kirstie L. Kaiser and Henry W. Chaney. The fieldwork in 2013 and 2014 was carried out by KGM aboard the Undersea Hunter as part of the Expeditions by CIMAR-UCR, lead by Juan José Alvarado and Jorge Cortés, and funded by Conservation International. We want to thank Jorge Cortés and the crew of DeepSee Submersible/Undersea Hunter Group for providing the images of Berthella californica, Doriopsilla cf. spaldingi and Flabellina sp. We thank Jeffrey Sibaja-Cordero who collected and photographed Peltodoris rubra. Carolina Salas-Moya and Juan Manuel Camargo who collected and photographed Anteaeolidiella ireneae, and Felipe López Pozuelo who photographed Glaucus cf. marginatus. Angel Valdés and Terry Gosliner helped us to identify the species Doriopsilla cf. spaldingi. Kirstie Kaiser, Hans Bertsch and two other anonymous reviewers make constructive comments to this manuscript.

\section{RESUMEN}

Nuevos registros de babosas marinas (Mollusca: Gastropoda) del Parque Nacional Isla del Coco, Costa Rica: La fauna de moluscos de la Isla del Coco ha sido bien documentada; sin embargo, los moluscos heterobranquios o babosas marinas (tradicionalmente llamadas opistobranquios) continúan siendo poco conocidos. Aquí agregamos 13 nuevos registros, incrementando el total a 40 especies. De estas 13 especies, las siguientes no han sido reportadas en la costa continental del Pacífico de Costa
Rica: Berthella californica (Dall, 1900), Peltodoris rubra (Bergh, 1905), Dendrodoris albobrunnea Allan, 1933, Doriopsilla cf. spaldingi Valdés \& Behrens, 1998, Glaucus cf. marginatus (Reinhardt \& Bergh, 1864) y Flabellina sp. Informamos por primera vez la presencia de Peltodoris rubra en el Pacífico Tropical Oriental.

Palabras clave: Heterobranchia, Nudipleura, Sacoglossa, Aplysiomorpha, opisthobranquios, biodiversidad, nuevos registros, Isla del Coco.

\section{REFERENCES}

Alvarado-Induni, G. E. (2000). Volcanes de Costa Rica: Geología, historia y riqueza natural. San José, Costa Rica: EUNED.

Barraza, J. E. (2009). Opistobranquios de El Salvador. San Salvador, El Salvador: Ministerio de Medio Ambiente y Recursos Naturales.

Behrens, D. W. (2004). Pacific coast Nudibranchs, Suplemeent II. New species to the pacific coast and new information on the Oldies. Proceedings of the California Academy of Sciences, 55(2): 11-54.

Behrens, D. W., \& Hermosillo, A. (2005). Eastern Pacific Nudibranchs. A guide to the Opisthobranchs from Alaska to Central America. Monterey, California: Sea Challengers.

Bertsch, H. (2008). Opistobranquios. In G. D. Danemann \& E. Ezcurra (Eds.), Bahía de los Ángeles: Recursos naturales y comunidad. Linea base 2007 (pp. 319338). México, D.F.: Instituto Nacional de Ecología.

Bertsch, H. (2014). Biodiversity in La Reserva de la Biósfera Bahía de los Ángeles y Canales de Ballenas y Salsipuedes: Naming of a new genus, range extensions and new records, and species list of Heterobranchia (Mollusca: Gastropoda), with comments on biodiversity conservation within Marine Reserves. The Festivus, 46(5): 158-177.

Bruno, J. F., \& Bertness, M. D. (2001). Habitat modification and facilitation in benthic marine communities. In M. D. Bertness, S. D. Gaines \& M. E. Hay (Eds.), Marine Community Ecology (pp. 201-218). Sunderland, MA: Sinauer.

Camacho-García, Y. (2009). Benthic Opisthobranchs. In I. S. Wehrtmann \& J. Cortés (Eds.), Marine Biodiversity of Costa Rica, Central America (pp. 371-386). Berlin, Germany: Springer Science + Business Media B.V.

Camacho-García, Y. E., \& Gosliner, T. M. (2008). Nudibranchs dorids from the Pacific coast of Costa Rica with description of a new species. Bulletin of Marine Science, 83(2): 367-389.

Camacho-García, Y., Gosliner, T. M., \& Valdés, A. (2005). Field Guide to the Sea Slugs of the Tropical Eastern 
Pacific. San Francisco, California: California Academy of Sciences.

Carmona, L., Pola, M., Gosliner, T. M., \& Cervera, J. L. (2013). A tale that morphology fails to tell: a molecular phylogeny of Aeolidiidae (Aeolidida, Nudibranchia, Gastropoda). PLoS ONE, 8: e63000. doi:10.1371/journal.pone.0063000.

Carmona, L., Bhave, V., Salunkhe, R., Pola, M., Gosliner, T. M., \& Cervera, J. L. (2014). Systematic review of Anteaeolidiella (Mollusca, Nudibranchia, Aeolidiidae) based on morphological and molecular data, with a description of three new species. Zoological Journal Linnean Society, 171(1), 108-132.

Churchill, C. K. C., Alejandrino, A., Valdés, A., \& Foighil, D. Ó. (2013). Parallel changes in genital morphology delineate cryptic diversification of planktonic nudibranchs. Proceedings of the Royal Society, Biological Sciences, 280, 20131224.

Churchill, C. K. C., Valdés, A., \& Foighil, D. Ó. (2014). Molecular and morphological systematics of neustonic nudibranchs (Mollusca: Gastropoda: Glaucidae: Glaucus), with descriptions of three new cryptic species. Invertebrate Systematics, 28, 174-195.

Cortés, J. (1997). Biology and geology of eastern Pacific coral reefs. Coral Reefs, 16, (Suppl.), S39-S46.

Cortés, J. (2008). Historia de la investigación marina de la Isla del Coco, Costa Rica. Revista de Biología Tropical, 56(Supplement 2), 1-18.

Cortés, J. (2012). Marine biodiversity of an Eastern Tropical Pacific oceanic island, Isla del Coco, Costa Rica. Revista de Biología Tropical, 60(Supplement 3), 131-185.

Cortés, J., \& Blum, S. (2008). Life to 450m depth at Isla del Coco, Costa Rica. Revista de Biología Tropical, 56(Supplement 2), 189-206.

Dayrat, B. (2010). A monographic revision of basal Discodoris sea slugs (Mollusca: Gastropoda: Nudibranchia: Doridina). Proceedings of the California Academy of Sciences, 61, 1-403.

Fernández, C. (2008). Flora marina del Parque Nacional Isla del Coco, Costa Rica, Pacífico Tropical Oriental. Revista de Biología Tropical, 56(Suplemento 2), 57-69.

García-García, F. J., Domínguez, M., \& Troncoso, J. S. (2008). Opistobranquios de Brasil: Descripción y distribución de opistobranquios del litoral de Brasily del Archipiélago Fernando de Noronha. Vigo, Spain: Feito, S. L.

García-Méndez, K. (2015). Asociaciones entre moluscos Heterobranquios (Mollusca: Gastropoda) y macroalgas en el Pacífico de Costa Rica. (Licenciatura Thesis). Universidad de Costa Rica, San José, Costa Rica.

Gosliner, T. M. (1991). The opisthobranch gastropod fauna of the Galapagos Islands. In M. J. James (Ed.),
Galápagos Marine Invertebrates: Taxonomy, Biogeography and Evolution in Darwin's Islands (pp. 281-305). New York, US: Plenum Press.

Gosliner, T. M., \& Kuzirian, A. (1990). Two new species of Flabellinidae (Opisthobranchia: Aeolidacea) from Baja California. Proccedings of the California Academy of Sciences, 47, 1-15.

Gosliner, T. M., Behrens, D. W., \& Valdés, A. (2008). IndoPacific Nudibranchs and Sea Slugs. A field guide to the World's most diverse fauna. California. USA: Sea Challengers Natural History Books \& The California Academy of Sciences.

Hermosillo, A. (2004). Opisthobranch mollusks of Parque Nacional de Coiba, Panamá (Tropical Eastern Pacific). The Festivus, 36(9), 105-117.

Hermosillo, A., Behrens, D. W., \& Ríos-Jara, E. (2006). Opistobranquios de México: Guía de babosas marinas del Pacífico, Golfo de California y las islas oceánicas. Mexico, D.F.: CONABIO.

Kaiser, K. L. (2007). The recent molluscan fauna of Île Clipperton (Tropical Eastern Pacific). The Festivus, 39, 1-162.

Klussmann-Kolb, A., \& Dinapoli, A. (2006). Systematic position of the pelagic Thecosomata and Gymnosomata within Opisthobranchia (Mollusca, Gastropoda)-revival of the Pteropoda. Journal of Zoological Systematics and Evolutionary Research, 44(2), 118-129.

Lalli, C. M., \& Gilmer, R. W. (1989). Pelagic Snails: The Biology of Holoplanktonic Gastropod Mollusks $\square$. Stanford, USA: Stanford University Press.

Lizano, O. G. (2001). Batimetría de la plataforma insular alrededor de la Isla del Coco, Costa Rica. Revista de Biología Tropical, 49(Supplement 2), 163-170.

MacFarland, F. M. (1905). A preliminary account of the Dorididae of Monterey Bahía, California. Proceedings of the Biological Society of Washington, 18, 35-54.

Montoya, M. (1983). Los moluscos marinos de la Isla del Coco, Costa Rica, I. Lista anotada de especies. Brenesia, 21, 325-353.

Mulliner, D. K. (1993). Opisthobranchs of Cocos Island. Annual Report of the Western Society of Malacologists, 25, 2-3.

Nakamura, K. (2006). New records of opistobranch mollusks from the Guayaquil marine ecoregion: northern Perú. The Festivus, 38: 75-83

Rojas, W., \& Alvarado, G. E. (2012). Geología y contexto geotectónico de la Isla del Coco y la zona marítima frente al Pacífico Central de Costa Rica. Revista de Biología Tropical, 60(Supplement 3), 15-32.

San Martín, G., López, E., Redondo, M. S., Capa, M., Caldera, P., \& Lagorda, J. (1997). El bentos marino del 
Parque Nacional de Coiba. In S. Castroviejo (Ed.), Fauna y Flora del Parque Nacional de Coiba, (Panamá). Inventario preliminar (pp. 33-37). Madrid, Spain: Agencia Española de Cooperación Internacional.

Sánchez, C. A. (2000). Biodiversidad de moluscos opistobranquios (Mollusca: Opisthobranchiata), del Pacífico mexicano: Isla Cedros- Vizcaíno e islas del Golfo de California parte Sur. Universidad Autónoma de Baja California Sur. Informe final SNIB-CONABIO proyecto No. L136. México, D.F.

Sibaja-Cordero, J. A, García-Méndez, K., \& Troncoso, J. S. (2013). Additions to the mollusk checklist of Cocos Island National Park, Costa Rica (Eastern Tropical Pacific). Iberus, 31(2), 127-163.
Valdés, A., \& Behrens, D. W. (1998). A new species of Doriopsilla (Mollusca, Nudibranchia, Dendrodorididae) from the Pacific Coast of North America. Proceedings of the California Academy of Sciences. 50(13), 307-314.

Valdés, A., \& Camacho-García, Y. E. (2004). “Cephalaspidean" heterobranchs (Gastropoda) from the Pacific coast of Costa Rica. Proceedings of the California Academy of Sciences, 55, 459-49.

Wägele, H., Vonnemann, V., \& Rudman, W. B. (2006). Umbraculum umbraculum (Lightfoot, 1786) (Gastropoda, Opisthobranchia, Tylodinoidea) and the synonymy of $U$. mediterraneum (Lamarck, 1812). Records of the Western Australian Museum, 69, 69-82. 
